\title{
Ardeth
}

A magazine on the power of the project

$7 \mid 2020$

Europe

\section{Translocality as Urban Design Tool for the Inclusive City: The Case of Europan}

Socrates Stratis

\section{(2) OpenEdition \\ 1 Journals}

Electronic version

URL: https://journals.openedition.org/ardeth/1768

ISSN: 2611-934X

\section{Publisher}

Rosenberg \& Sellier

Printed version

Date of publication: 1 December 2020

Number of pages: $25-45$

ISSN: 2532-6457

\section{Electronic reference}

Socrates Stratis, "Translocality as Urban Design Tool for the Inclusive City: The Case of Europan", Ardeth [Online], 7 | 2020, Online since 01 June 2021, connection on 25 June 2021. URL: http:// journals.openedition.org/ardeth/1768 


\section{Translocality as Urban Design Tool for the Inclusive City: The Case of Europan}

Socrates Stratis

Abstract

In this article, I unpack the notion of translocality as an urban design tool that interrelates architecture, infrastructure and territory in Europe. The notion of translocality entails a strategic design tool to form specific relations between mobility and place towards the goal of a European inclusive city. Translocality involves mobility as an agent for co-producing locality as well as territories as hosts for place-making mobilities. I argue that Europan, a 30-year-old biennial urban design competition network for ideas and their implementation, has discreetly set the foundations for collectively addressing the inclusive city, offering many kinds of translocality. The article is based on the examination of diaries and notes of the author's reflective practice thanks to his involvement in the Europan network. In addition, it examines the documents produced by the reflective practice of Europan. The findings help us formulate a strategic framework for collaborative European networks of urban design that can instigate common urban imaginaries for the inclusive city.
Affiliatio

University of

Cyprus, Department of Architecture

Contacts: stratiss [at] ucy [dot] ac [dot] cy

Received:

31 March 2020

Accepted: 16 December 2020

DOI:

10.17454/ARDETH07.03

ARDETH \#07 


\section{Translocality as a design tool encourages urban design practice to profit from the interrelationship between means and ends.}

\section{Introduction}

Through this article, I unpack the notion of translocality as an urban design tool to interrelate architecture, infrastructure and territory in Europe, the topic of the current issue of "Ardeth" journal. Translocality is the opposite of globalization. It revolves around putting local issues in a global context, making them accessible. The notion of translocality can form a strategic design tool that creates specific relations between mobility and locality to enhance the inclusive city. Translocality as a design tool encourages urban design practice to go beyond the dominating visual and static aesthetics of the discipline. Moreover, it introduces design-based research to complement urban design research that focuses on temporal and perceptual dimensions of the urban environment (Wenderlich, 2014: 61). Translocality as a design tool encourages urban design practice to profit from the interrelationship between means and ends. In other words, it brings forward the correlation between the actorial ecology of the urban design process and the content of the design proposal.

Having said that, I argue that Europan has discreetly set the foundations for collectively addressing the European inclusive city, based on many facets of translocality. Europan is simultaneously a centralized organization based in Paris and a network spread out over 23 European countries. It is a 30-year-old biennial urban design competition platform for ideas and their implementation. Since 1988, it has mobilized 20,370 teams of young practitioners under 40 years old, who delivered proposals for 530 sites in 23 European countries (Vincendon, 2019).

So far, we have assumed that the inclusive city will emerge thanks to many bottom-up spatial practices based on the agency of participation. However, this is not enough. We may also need a strategic approach that will allow for isolated practices coming from small cities around Europe to ally, exchange ideas and share designerly knowledge. According to Michelle Provoost, the way we conceptualize, build and manage our cities determines their democratic content (Provoost, 2017: 81). Provoost suggests that after having mastered bottom-up initiatives and small projects, we actually need to construct bridges between civic institutions and public, democratic structures. 
Collaborative networks aim at creating such bridges by investing in the intersection of design, social innovation and public policy (Manzini, Staszowski, 2013). The Europan network has the seeds to our cities' democratic content and can offer the aforementioned bridges and interrelations. Its network-like structure allows for a collective intelligence to emerge (Kalnis, 2016). It is true that the Europan organization does not deal with bottom-up initiatives but rather with local authorities' urban practices. Nor does it present itself explicitly as a collaborative network. Yet, the concept of translocality may make explicit such potential. It can offer a thread bringing together the fragmented urban design knowledge on relations between mobility and place produced by the network. Such a thread may be useful for constructing bridges to civic institutions and between isolated winning projects, Europan's practice and urban actors. It may also offer elements of innovation to urban design practice outside the competition.

The research methodology of this article is based on a qualitative method of inquiry with the support of some data I have collected over the years as well as data produced by the Europan network. I use two tracks of inquiry. The first one is the examination of diaries, notes and articles produced by my reflective practice thanks to my involvement in the network. The second track is the examination of documents produced thanks to the reflective practice of Europan (published projects and texts, exhibitions, fora and conferences, etc). The findings first demonstrate the multiple facets of translocality present in its activities as a network as well as in the winning projects. Second, they help us formulate a strategic framework by offering alternative futures for the European inclusive city through urban design practice.

\section{Translocality}

The two central dimensions of translocality are those of mobility and place (Greiner, Kdapolrak, 2013).

The notion of translocality is first used by Appadurai when he defines the effects of transnational processes on localities, especially addressing issues of migration. According to Appadurai, it is becoming increasingly difficult to produce localities devoid of such processes (Appadurai, 2005). Other scholars complement this

It is true that
the Europan
organization
does not deal
with bottom-up
initiatives but
rather with local
authorities' urban
practices. Nor
does it present
itself explicitly as
a collaborative
network. Yet,
the concept of
translocality may
make explicit such
potential.

It is true that the Europan organization does not deal with bottom-up initiatives but rather with local authorities' urban practices. Nor as itself explicitly as a collaborative network. Yet, the concept of translocality may make explid
potential. 


\section{We see tension resulting from the conflict between the importance of social equity in mobility infrastructure (access and circulation) and unequal patterns of urbanization responsible for inequality and exclusion.}

approach by emphasizing place instead of mobility, introducing practices of emplacement, of anchoring of migration flows (Smith, 2011). Some people call it "situatedness during mobility", a sort of groundedness during mobility (Brickell, Datta, 2011). The notion of translocality was important to urban studies and later also to urban design, since it allows us to abandon binaries such as localism vs globalism and urges us to study how to insert local issues into the global context and investigate ways to make them widely accessible. Through the notion of translocality, we understand the connections of urban environments with the world. We understand the effects of all kinds of networks on urban territories, especially when we realize that the production of localities is difficult without the transnational processes based on such networks of mobility.

Translocality causes, however, unequal urban development. In the 1980s, Francois Ascher introduced the notion of Metapolis to explicate this pattern of unequal urbanization based on mobility infrastructure and logistics nodes (Ascher, 1995). We see tension resulting from the conflict between the importance of social equity in mobility infrastructure (access and circulation) and unequal patterns of urbanization responsible for inequality and exclusion.

What kind of translocality is needed for the inclusive city? In other words, what kind of relations between mobility and place should urban design champion? For the purpose of this article, I define translocality as the interrelationship between the urban environment as an active container of mobilities and mobility as an active agent of urbanity (Fig. 1). The article tackles two questions. The first is what kind of mobility has an elevated degree of active agency in the co-production with locality of place? The second question is how territories could be prepared to become equal agents in the co-production of place; in other words, to become active hosts to place-making mobilities.

Mobility as an active agent of urbanity. Mobility constitutes an undeniable mode of "urbanogenesis". It is part of the fundamental practice that creates urbanity (Levy, 1999, 2004; Amphoux, 1999). Mobility is part of the means that generate co-presence. It constitutes one of the places where co-presence emerges. "Random 


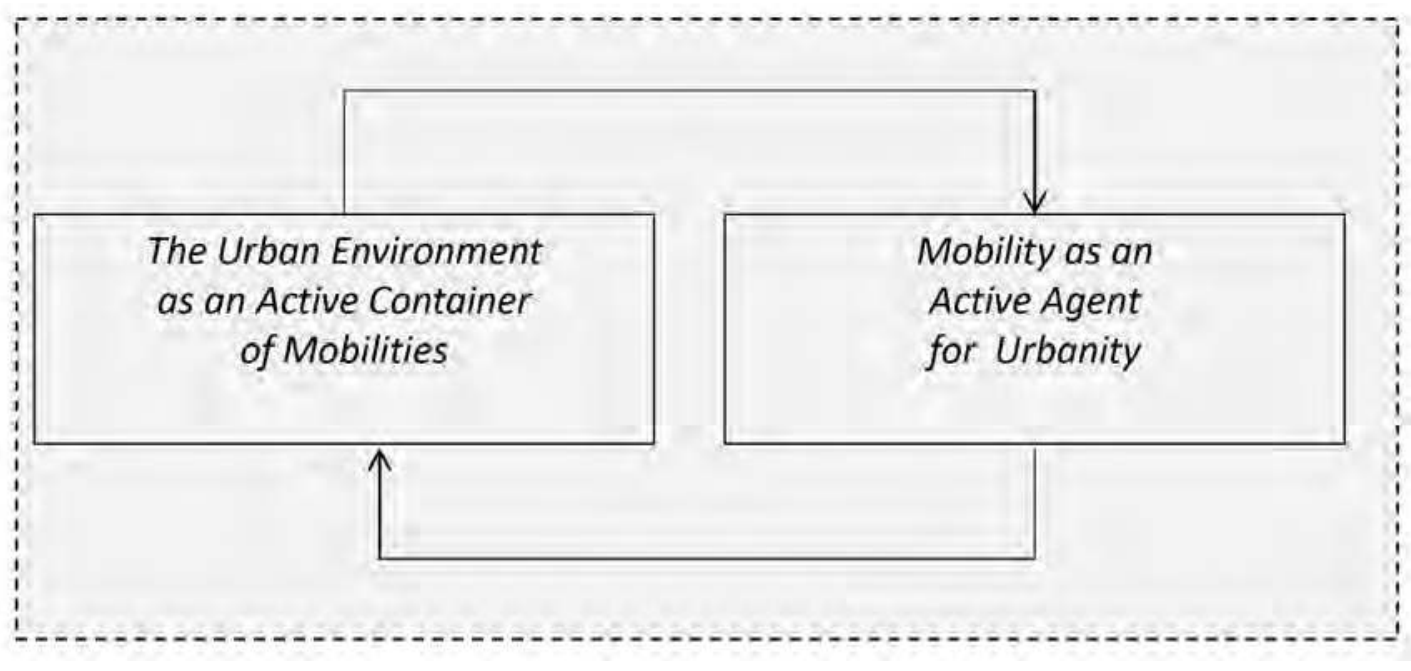

Multisensory Interactions on Contact” are central to the production of co-presence thanks to mobility. Levy unpacks how to maximize the aforementioned interactions by orchestrating specific relations between territories and networks of mobility (Levy, 2004: 159); in other words, by decreasing the dominance of "nonlieux” (Augé, 1993). Levy argues that since mobility plays such a decisive role in urbanity, it should not be regarded as a merely technical issue managed by experts. It should open up to democratic processes of decision-making (Levy, 2004: 169).

The urban environment as an active container of mobilities. The urban milieu is the agent of potential conciliation between all speeds of movement, modes of displacement and needs of the inhabitants and users. Donald Appleyard demonstrated how the expansion of our home territory is influenced by the amount of mechanized traffic crossing our streets. It showed, for the first time, the invisible impact of mechanized mobility on social relations in the urban environment (Appleyard, 1982). This kind of conciliation involves the use of mobility networks that introduce spatial, landscape and social relations to territories. Cities have many historical examples where mobility transcended its technical world to instill such relations in territories, from Moses' park avenues to Haussmann's restructuring of Paris, among many others (Degros, 2014: 36). Yet, the modes of action need to be redefined to enhance such transformations
Fig. 1 - Translocality as urban design tool for the inclusive city. Courtesy of the author.

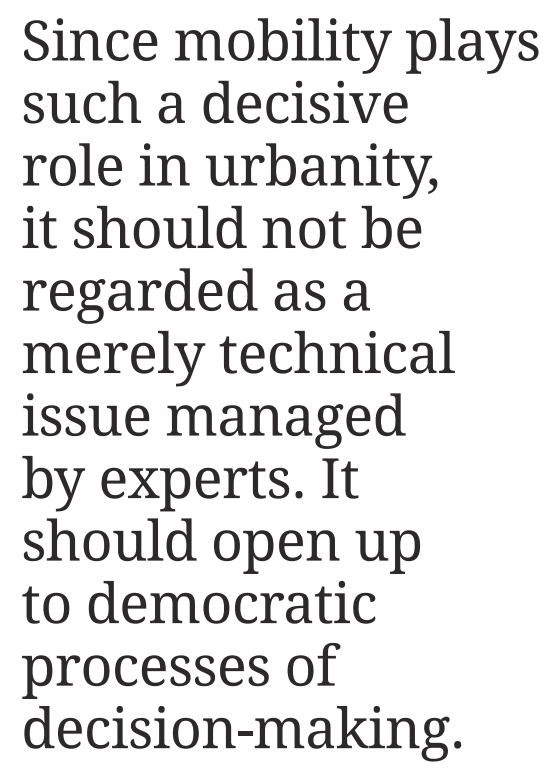

Since mobility plays such a decisive role in urbanity, it should not be regarded as a merely technical issue managed by experts. It should open up to democratic processes of decision-making. 
Fig. 2 - Visualiza-

tion of the actorial processes for the Europan project during each session. Courtesy of the author. to creatively address the co-presence of different rhythms (Younes, 2012), yielding the inclusive city. Slow structure, alludes to the idea of slowness. It involves the socialisation of networks by introducing different rhythms. In other words, it is about modes of action that work to integrate mobility networks into the social context based on slow and environmentally sensitive transport methods (Degros, 2014: 40, 41). Rethinking mobility may engender reconnections between entities kept apart by functionalist modernist urbanism: mobility, urban tissue and natural environment (Rebois, 2013: 94; Ascher, Appel-Muller, 2007). In addition, rethinking modes of soft as well as public mobility regarding housing areas in rural areas and their connection to cities could support the sustainability of the urban environment, addressing issues related to climate change and social injustice (Degros, 2019).

Europan, the most discreet city planning competition "Europan: the most discreet city planning competition, (but the smartest one)" is the title of Sibylle Vincendon's article in French daily newspaper Liberation, published on 9 May 2019. She had been following the French celebration of the $30^{\text {th }}$ anniversary of the biennial European Competition for young professionals (architects, urban planners, landscape architects). Vincendon's article refers to the European dimension of the competition, which serves discreetly as a network platform for launching innovative design ideas on the reinvention of the European city, and encouraging their implementation in the competition sites. Vincendon goes on to tell us that Europan has become an important urban device thanks to on one hand, the competent participating teams in each session of the biennial competition and on the other hand thanks to the 45 to 50 challenging competition sites all over Europe and to the high-level national juries. I could also include cities' authorities, sites' owners and city developers, the national secretariats of the actual 12 country members and the Scientific and Technical Committees. The network is localized twice for each biennial session, thanks to some strategically designed Fora by the European and national secretariats. The first Forum is that of the Inter Sessions, which is about the latest session's results combined with the 


\section{Theme Formulation: European Urbanities}

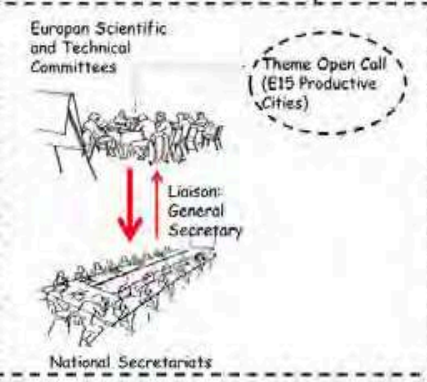

3. Informing the Subthemes From the Sites Specifics (grouping and comparing): ie, Europan 8

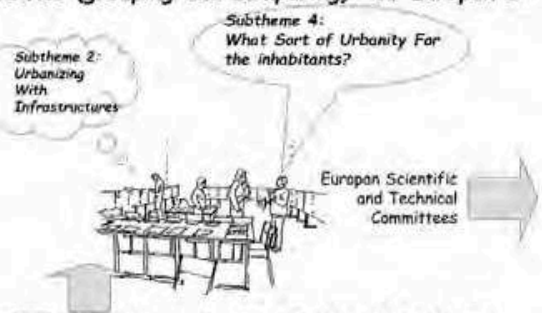

12. National Secretariats negotiate with cities' ' with relevant sites to the theme

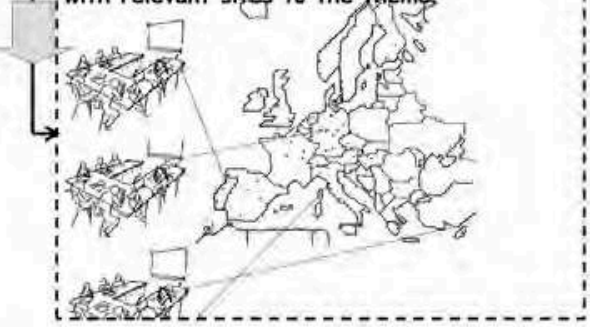

5. COMPETITION PHASE FOR ALL YOUNG ARCHITECTS, LANDSCAPE ARCHITECTS URBAN PLANNERS UNDER 40 YEARS OLD

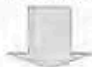

6. NATIONAL JURIES - FIRST STAGE

9. Forum of Results(combined with the following Esession forum of Sites)
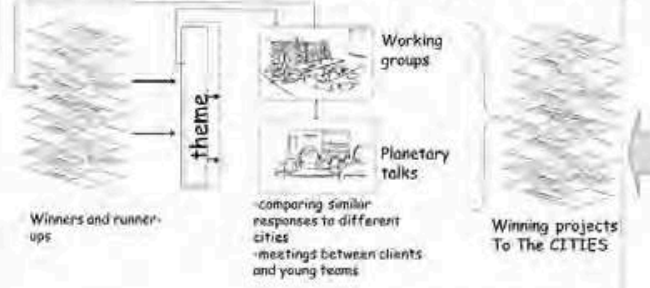

Winning projects
To The crIIES

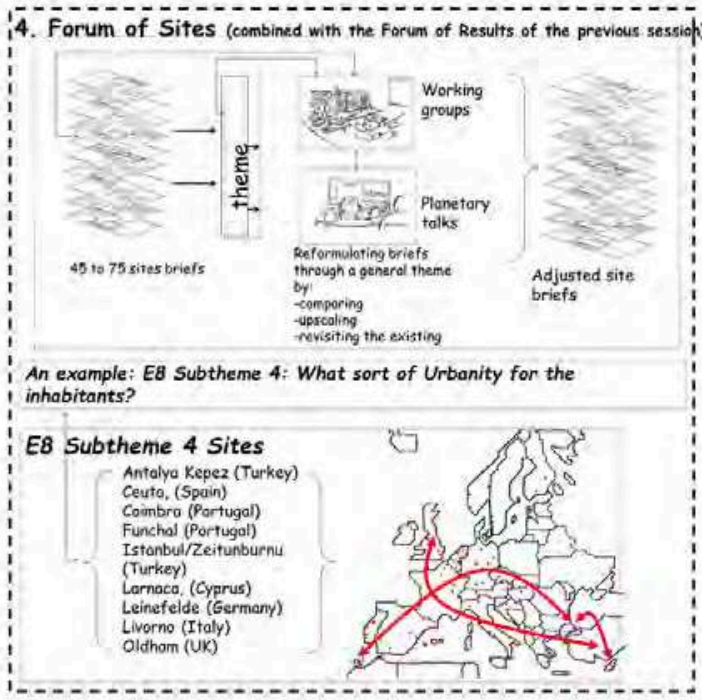

7. Forum of Cities and Juries

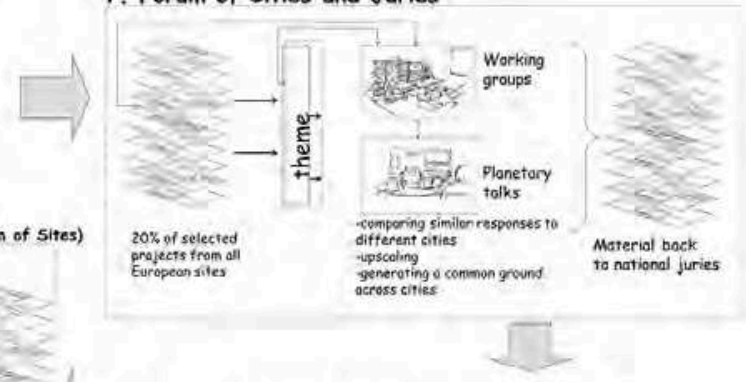

8. NATIONAL JURIES- SECOND STAGE

10. IMPLEMENTATION STAGE 
A process of
translation takes
place, allowing
local issues to reach

a European level of discussion and vice

versa.

\section{Europan is an incredible place where young professionals could win by challenging the brief and reformulating the initial brief's questions.}

following session's debate on the new sites. The second one is the Forum of Cities and Juries that allows for a European discussion based on a selection of $20 \%$ of submitted projects by each national jury (Fig. 2). Both Fora are active advocates for the sustainability of Europan as a collaborative network.

Europan started in 1988 thanks to an expansion of the French organization Pan (Programme Architecture Nouvelle - New Program for Architecture). The establishment of Pan in 1972 aimed to break away from the dominating architectural powers and to prepare the grounds for a new generation (Maugard, Younes, 2019: 9). Europan's objective, similar to that of Pan, facilitates practitioners under 40 years old in collaborating with European city authorities via innovative projects concerning the urban environment. The unique character of the biennial competition comes from a dynamic relation between innovative ideas and their implementation, between designed processes and projected physical objects. Therefore, it allows for experimentation, for the reformulation of badly posed questions, or for the formulation of new questions about the future of sites. Moreover, according to the mayor of Besancon, France participating in a working group of the 2018 Europan 14 Forum in Brussels, it enables the participating teams, cities and the rest of the urban actors involved to gradually construct common concerns and visions about the European inclusive city. A process of translation takes place, allowing local issues to reach a European level of discussion and vice versa.

The $30^{\text {th }}$ anniversary of Europan France in 2018 was celebrated through a film documentary, a conference, a book titled Villes et architectures en débat - Europan written by Chris Younes and Alain Maugard (2019), radio programmes and articles in newspapers. The last two addressed a wider audience, hoping to make Europan less discreet, at least in France. According to Alain Maugard, President of Europan France who was interviewed in Vincendon's article in Liberation, Europan is an incredible place where young professionals could win by challenging the brief and reformulating the initial brief's questions. The conference was part of the 30-year anniversary celebrations of Europan France and brought French-speaking urban actors together. The debate centred on the future of the network, its challenges, its practices regarding changes in professional practice and society as well as in urban governing institutions (Stratis, 2019). 
Research methodology: Europan's collective reflective practice

The article's research methodology is based on a qualitative method of inquiry with the support of some data I have collected over the years as well of additional data produced by the Europan network. I use two tracks of inquiry. The first is the examination of diaries, notes and articles I produced during my reflective practice in Europan, in which I have been involved in multifarious ways since 1996 (Stratis, 2019). The second track involves the examination of documents produced thanks to the reflective practice of the network, producing collective intelligence (Kalnis, 2016): catalogues of results with analytical texts and presentations of the winning projects, exhibitions catalogues and web archives of Europan Europe and the national structures. The European and national structures of the organization have established some exceptional moments of reflection along with their mundane role of organizing the biennial competitions, yet not in a systematic way. As I mentioned already, Europan France celebrated its 30 years in 2018 by establishing modes of reflection on the organization's activities and design output. Europan Europe has initiated a few similar events, inviting all participating countries to contribute. In 1996, there was the milestone event in Thessaloniki, Greece, regarding the implemented projects from previous sessions. In 2007, Didier Rebois, the General Secretary of the organization and one of its founding members, curated an exhibition in Cité d'Architecture in Paris and edited a book titled Generation Europan. In 2009, he initiated, together with the members of the organization's Scientific committee, a major event in Graz, Austria, titled "What Future for Europan Competition?” (Rebois, 2009), with a publication of the same title. Some of the winning projects that I analyse come from this publication.

In their turn, the national structures of the organization have managed to reflect on their practice a few times during the last 30 years (Stratis, 2019). The outcome of Europan's reflective posture is a valuable source of empirical knowledge about European urban design. Its reflective capacity has enabled me to further develop the notion of translocality as design tool. The relations between mobility and place that constitute the notion of translocality have been the

\section{The outcome of Europan's reflective posture is a valuable source of empirical knowledge about European urban design.}


Only 50\% of winning projects of Europan's 10

to 14 sessions

(E10-E14) are

implemented. Even

though the cities

pay quite a lot to

participate, they do

not mind avoiding

implementation.
The meaning

of successful

implementations

changes when we

include into urban

design practice,

activities that relate

to processes and

regulations, to

strategic plans and

tactful actions. object of discussion by jury members, winning teams and cities' representatives during working groups of the various sessions. They have also been the object of analysis of winning projects in the literature (Amphoux, 1999; Degros, 2014; Hamfelt, 2004; Rebois, 2008; Stratis, 2006, 2016).

Further on, I will use the notion of translocality to revisit the Europan's activities. I identify two conditions of translocality that bound its activities. The first has to do with the placement of local issues of cities in European networks of urban actors during the process of each session of the biennial competition. The second one has to do with the envisioned relations between mobility and place by the winning projects, regarding the competition sites.

Placement of local issues of cities in the Europan's many networks of urban actors

Mid-May 2019, the national structures of the organization, together with the scientific committee, met in Stockholm and discussed the fact that only 50\% of winning projects of Europan's 10 to 14 sessions (E10-E14) are implemented. Even though the cities pay quite a lot to participate, they do not mind avoiding implementation. Besides, young professionals continue to show great interest in the competition, despite increasing chances of non-implementation.

This meeting was part of the network's desire to systematize its reflective practice by bringing together local issues on a European scale. With the help of the national structures, Didier Rebois systematically gathers relevant data, both quantitative and qualitative, to help the network with a continuous readjustment. Part of this data formed the basis of the discussion in Stockholm, together with stories of successes and failures during the implementation of winning projects from all over Europe.

The meaning of successful implementations changes when we include into urban design practice, activities that relate to processes and regulations, to strategic plans and tactful actions. Then, we can move away from the idea of urban design as a sum of designed physical objects. This kind of debate among the network's actors was triggered by emblematic winning projects and relevant published articles about Europan. I coined the idea of revealing the "iceberg" character of the Europan project with Bernd Vlay in 


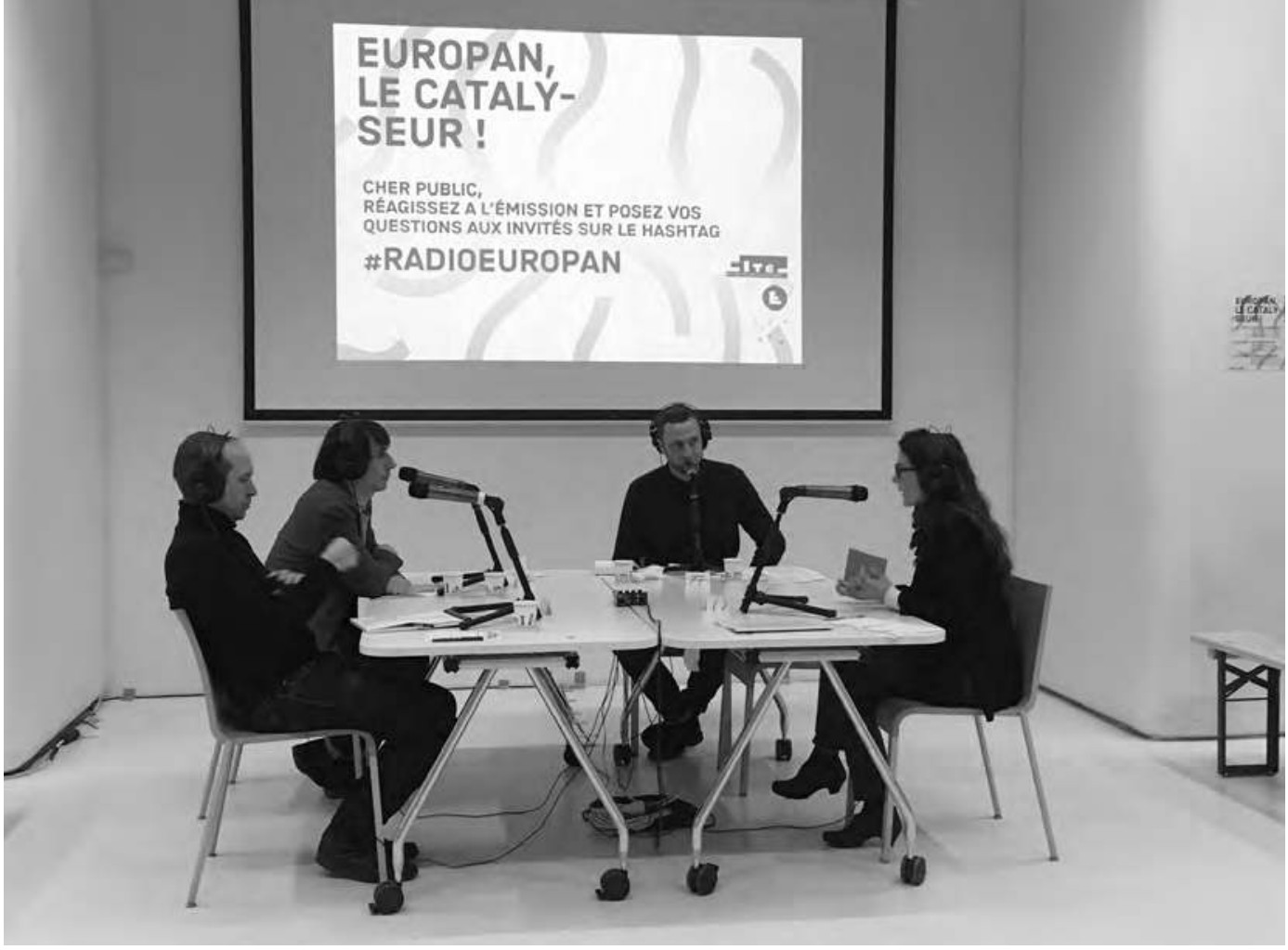

2010 to celebrate the invisible aspects of the urban design project, which architectural culture tends to ignore (Vlay, Stratis, 2010).

After all, cities do not mind avoiding implementation because they gain considerably from the immaterial dimensions of the project concept as well as from the critical mass of the network. They publicize their cities through the competition site, both in their countries and across Europe. They get valuable ideas and insights on how space could be used for political programs and urban visions, plus they meet each other. The young professionals, on a similar note, get to test their wings and their ability to deal with complex urban issues. In some countries, like France for example, the winning teams enter into a palmares (roll of honour), of candidates, very attractive to other cities and public institutions.

In December 2018, in a radio broadcast titled $\mathrm{Eu}$ ropan the catalyst (Europan le catalysateur) (Fig. 3) that was part of Europan France's $30^{\text {th }}$-anniversary celebration, city representative of Marseille Mrs Laure Portale talked with great enthusiasm about the city's experience with the winning teams regarding the Plan d'Aou area (Europan 12- E12). One of the three
Fig. 3 - View of the radio program debates, 2019. Courtesy of the author.
Cities do not mind avoiding implementation because they gain considerably from the immaterial dimensions of the project concept as well as from the critical mass of the network. 
1 - excerpt from the

E11 Forum of Cities Istanbul, Workshop

3C From Place to

Territory Report,

2010, written by the author.

\section{2 - https://www.} europan-europe.eu/ fr/project-and-processes/promotor.

\section{The "Promotor"} project shifts the urban design project into a web tool that collects and produces data regarding a transnational region. It is a web archive that improves social accessibility to urban-planning decision-making. winning teams, M. Hermansen, J.W. Frisk, R.W. Frisk, (Denmark), introduced an innovative participatory method, surprising the urban actors, who were rather accustomed to centralized French planning methods. "We were blocked! We had no idea about the future of the site before entering the competition", exclaimed Mrs Portale during the radio discussion. According to her, all winning teams helped the city open up its horizons of possibilities. On a similar line, during the Forum of Cities for the $11^{\text {th }}$ session of the competition, in Istanbul back in 2010, the urban planning director of Porvoo in Finland, Mr Eero Loytonen, had similar expectations from the network. He was hoping for new questions and programmes for his city, which were impossible to instigate by the city itself, to be produced by the participating European actors. $\mathrm{Mr}$ Michele Beaumale, the mayor of Stains in France, who participated in the same workshop, referred to the "possibility of Europan to become a facilitator of things to happen. To put the project actors around a table and discuss possibilities". ${ }^{1}$

"Promotor" is the name of the winning project at Kleines Dreieck by S. Langner and M. Rudolph (Germany), ${ }^{2}$ located at the eastern German borders (E8 session). It consists of an architecture of new actorial and programmatic proximities aimed at opening up regional planning to the Dreistadt region's inhabitants. The "Promotor" project shifts the urban design project into a web tool that collects and produces data regarding a transnational region. It is a web archive that improves social accessibility to urban-planning decision-making (Stratis, 2009: 28). It becomes a device that situates local issues, which are fragmented both due to national borders and the mode of master planning, on a global scale.

Envisioned relations between mobility and place in the winning projects

In this part, I will refer to the relations between mobility and place envisioned by some emblematic winning projects. The first relation involves place-making mobilities, and the second is about urban territories as active containers of mobility.

Place making mobilities is the characteristic of the following three winning projects. We will briefly see what kind of mobility has an elevated degree of active agency as it co-produces place with locality. 
"La ville de plus près" ("Bringing the town closer") is the runner-up project for Bordeaux, France, by

A. Bossé and N. Solenn, (France), (E9 session). The project "establishes a context within which the site can take time to grow in complexity and gain substance in terms of the building blocks of future practices and neighbourliness functioning at both local and city-wide levels" (from an interview published on europan.europe.eu). ${ }^{3}$ Soft mobility, in this case, obtains a situational character. In other words, the slowness of pedestrians and all sorts of non-mechanical flows becomes an agent of constructing situated shared knowledge among the users of the specific site. It is a sort of slow structure (Degros, 2014). It produces public space by populating the abandoned railway site where the city wants to build housing. In other words, the project offers alternative ways to develop the city through temporal uses and the establishment of sociability before the buildings arrive.

The winning project "Ambient Kerb" in Warsaw, Poland by L.G. Alfaya and P. Muniz (Spain) aims to preserve the existing atmosphere of the neighbourhood, part of the competition site, (E10 session). It employs interior furniture in the public space of the streets and the buildings' courtyards. When the residents of Warsaw regained their private properties in the existing courtyard buildings from the state, the next step was to question the publicness of the courtyard spaces. "Ambient Kerb"4 counters such privatization by offering temporal ways to encourage public flows through the courtyards.

The winning project by L'AUC (France) ${ }^{5}$ in Villetaneuse, France, introduced the variability of the duration of network flows and its impact on the place-making of public spaces in transport hubs (E5 session). The team implicitly translated Levy's approach to orchestrating relations between mobility networks and place to increase urbanity (Levy, 2004). Their brief or long duration depends on the type of programmes inserted in proximity to traffic nodes (Stratis, 2009: 28, 29). Urban territories as active containers of mobilities is the aim of the following six winning projects that implicitly addressed the question: how could territories be "prepared" to become equal agents in the co-production of place? To become, in other words, active hosts to place-making mobilities. Their answer
3 - https://www. europan-europe.eu/ fr/project-and-processes/bringingthe-town-closer

4 - https://www. europan-europe. eu/fr/project-andprocesses/ambientkerb

5 - https://www. europanfrance.org/ projet/corridoranti-potemkine-236

Soft mobility, in this case, obtains a situational character. In other words, the slowness of pedestrians and all sorts of nonmechanical flows becomes an agent of constructing situated shared knowledge among the users of the specific site. 
6 - http://europan. no/ukategorisert/ e11-skienporsgrunn/

7 - http://archive. europan.at/wi wien.html

8 - https://www. europanfrance. org/projet/bondy-scount-593

9 - https://www. europanfrance. org/projet/on-theroad-318 is twofold: by multiplying the hosting capacities of a place to urban flows and by strategically distributing those flows of network centralities over the territories in proximity.

Multiplication of hosting capacities: back in 1997, Villetaneuse was one of those territories not yet connected to transport networks. The winning project builds on the state's decision for a new train stop and a tram line by designing a public programme to be used by both passers-by and the neighbourhood. Another example is the runner-up project in Skien and Porsgrunn by N. Hack (Germany) and P. D'Acunto (Italy), (E11 session). ${ }^{6}$ The project offers four pedestrian bridges across the river to complete a soft mobility network and at the same time link the four isolated communities along the river. The bridges are populated with public programmes such as a spa and swimming pools. The teaming up of the cities of Skien and Porsgrunn for the competition helped increase their critical territorial mass, in a bid to multiply their hosting capacities for mobilities. Strategies of increasing the locality's resistance when the territories are overwhelmed by fast flows are the driving design force of the following projects.

In Kagran, Vienna, dominant flows are produced due to the presence of a large shopping centre. In Bondy, France, the flows are produced by the logistics area. The winning project in Kagran by B. Romanluc and D. Stupar, (Slovenia) ${ }^{7}$ challenges the suburban function of the shopping centre by introducing a major public space and changing how it can be accessed from the nearby train station (E13 session). The winning project in Bondy by N. Barnavon and collaborators (France) ${ }^{8}$ formulates a negotiation game (E13 session). It is an invitation for urban actors to support the infiltration of big box logistics areas by public spaces, street commerce and leisure activities. In Reims, France, the project brief has to do with urbanizing the $8 \mathrm{~km}$ long downscaled highway. The runner-up project by N. Reymond and Agence Beau Bour (France) ${ }^{9}$ proposes a series of micro-centralities along the downgraded highway to become part of a network of public spaces for the city (E9 session). In other words, it proposes integrating the mobility infrastructure in a social context. 
The winning project in Sion, Switzerland, by E. Gronn and I. Lyngner, (Norway) ${ }^{10}$ reorganizes the city's traffic by distributing the train station's traditional programmes along a city boardwalk, (E9 session). The team proposes to extend the soft mobility network to the other side of the railway by developing underground and overground connections.

Conclusion, or designerly translocalities for the inclusive European city

Placing Local Issues on Europan's Network: Europan's activities and the aforementioned winning projects show us many facets of translocality that engender new actorial proximities, a prerequisite for co-producing the inclusive city. To allow for such proximities to take place, we need to redefine the notion of the urban design project itself. Besides, we need to accept the open character of the project. More precisely, we should include the following in the making of a project: the process of the initial formulation of each session theme, the choice of sites, the invitation of urban actors on different scales, the formulation of the brief and the collective discussion of $20 \%$ of submitted projects on a European level (the Europan Forum of Cities and Juries). The Europan project allows young competition participants to reformulate the relations between all the above: to reposition the relations that enhance new proximities between mobility and locality for place co-production. The "Promotor" project in Kleines Dreieck is emblematic in that sense.

Having in mind that cities are the faithful clients of the network, we need to confront the challenges that come with such a collaboration. The first one is the inequality between European cities in terms of available funds and tools to address such issues. For example, the burden of the socialist state legacy in former Eastern European countries disempowers cities' positions. It hands over their urban future to the private sector. Concerning the cities coming from the north-western part of Europe, they still have some support from the state, thus they get more chances to successfully undertake the winning proposals. The second challenge is to open up the process of interrelating urban actors to a European reach, including more than just those from local authorities. Since 1988, when Europan was founded, we have seen the emergence of many new
10 - https://www. europan-europe. eu/fr/projectand-processes/ boardwalking
Having in mind that cities are the faithful clients of the network, we need to confront the challenges that come with such a collaboration. The first one is the inequality between European cities in terms of available funds and tools to address such issues. 


\section{They can all profit from the designerly approach of the network and vice versa.}

urban actors who deal with the city's commons. Some of them are grouped in European networks (URBACT for example). Others are organized in local groups, consisting of well-informed and engaged citizens. In addition, there are public institutions that deal with ecological transition and the increasing inequalities in our cities. They can all profit from the designerly approach of the network and vice versa.

Envisioned relations between mobility and place by Europan's winning projects

Regarding the aforementioned winning projects, they adopt quite often, a double posture. They reconfigure the assigned territories as urban containers for mobilities by multiplying their hosting capacities. At the same time, they use soft mobilities, to encourage urbanities. Bridges across a river can act as a programmatic node between a new locality and a soft mobility network (Skien and Porsgrunn). In Villetaneuse, it becomes clear that network flows can contribute to the locality if their duration of stay is extended in public spaces. In Bordeaux, the runner-up project questions the way we start a housing project. It employs soft mobility as an active agent to produce situated knowledge and encourage relations among users to reverse the urban development model by giving value to the public uses produced in the vacant site. It invites the city's inhabitants to claim an active role in the co-production of value for the project to come. In the Warsaw case, the project offers tools to sustain the public character of spaces.

To tackle such challenging issues, we should realize that the design decisions need to be addressed by urban actors who are sometimes trapped in nested scales and are thus not part of the usual processes of making urban design projects. I have examined, how the winning projects profit from design decisions already taken by such actors. Examples are the downscaling of French highways in Reims, the building of a new train station and tram line in Villetaneuse, the collaboration of two adjacent municipalities in Skien Polsgrum or that of three neighbouring countries in the Dreistadt region. Rather often, however, Europan needs more effective actorial synergies. By inviting urban actors responsible for mobility networks to join the network, Europan may support Levy’s urge to 
open the debate about the contribution of mobility infrastructures to urbanity up to democratic processes.

Collective imaginaries for the European inclusive city Europan reflects, on the one hand, the changes taking place in Europe since 1988 as regards the diminishing urban role of the welfare state and the increase in private urban development. On the other hand, it continues to provide alternatives to the laisser-faire mode of urbanization propelled by globalization. I am aware that in this article, I am referring to design intentions instead of concrete transformation on the ground. That could be the focus of another article. However, urban design intentions, such as those of the Europan winning projects, are useful for creating collective images of what is possible that can assign a political role to urban design. Images of what is possible can trigger a change in the operative imaginaries of European urban actors who have been taken over by the laisser-faire, neoliberal mode of urbanization. Europan's challenge is to systematize the rich designerly knowledge and know-how regarding the active agency of mobility in the co-production of locality as well as the preparation of territories to become active hosts for place-making mobilities. They need to become more accessible to international debates on the city and urban design practice. It can support the process of democratizing decisions taken about mobility infrastructures and their relation to territories. The construction of bridges between cities and civic institutions can take place thanks to processes of translocality as an urban design tool. Thus, Europan can help determine cities' democratic content by impacting how cities orchestrate new relations between mobility and place through encouraging cities to continue to be part of a European collaborative network.

Over the last 30 years, Europan has built a ground reality that should be shared with the rest of urban design scholars and practitioners. It has investigated 530 sites from many European cities for the competition (Fig. 4). This ground reality manifests itself in implemented projects, cities' strategic urban plans, the mobilization of urban actors across Europe and the mediatization of new shared urban futures. The on-going public health crisis will inevitably influence Europan, since it will most probably affect the social
Europan's challenge is to systematize the rich designerly knowledge and know-how regarding the active agency of mobility in the co-production of locality. 
Fig. 4 - The map of Europe formed by the cities participated in Europan since 1988. Courtesy of the author.

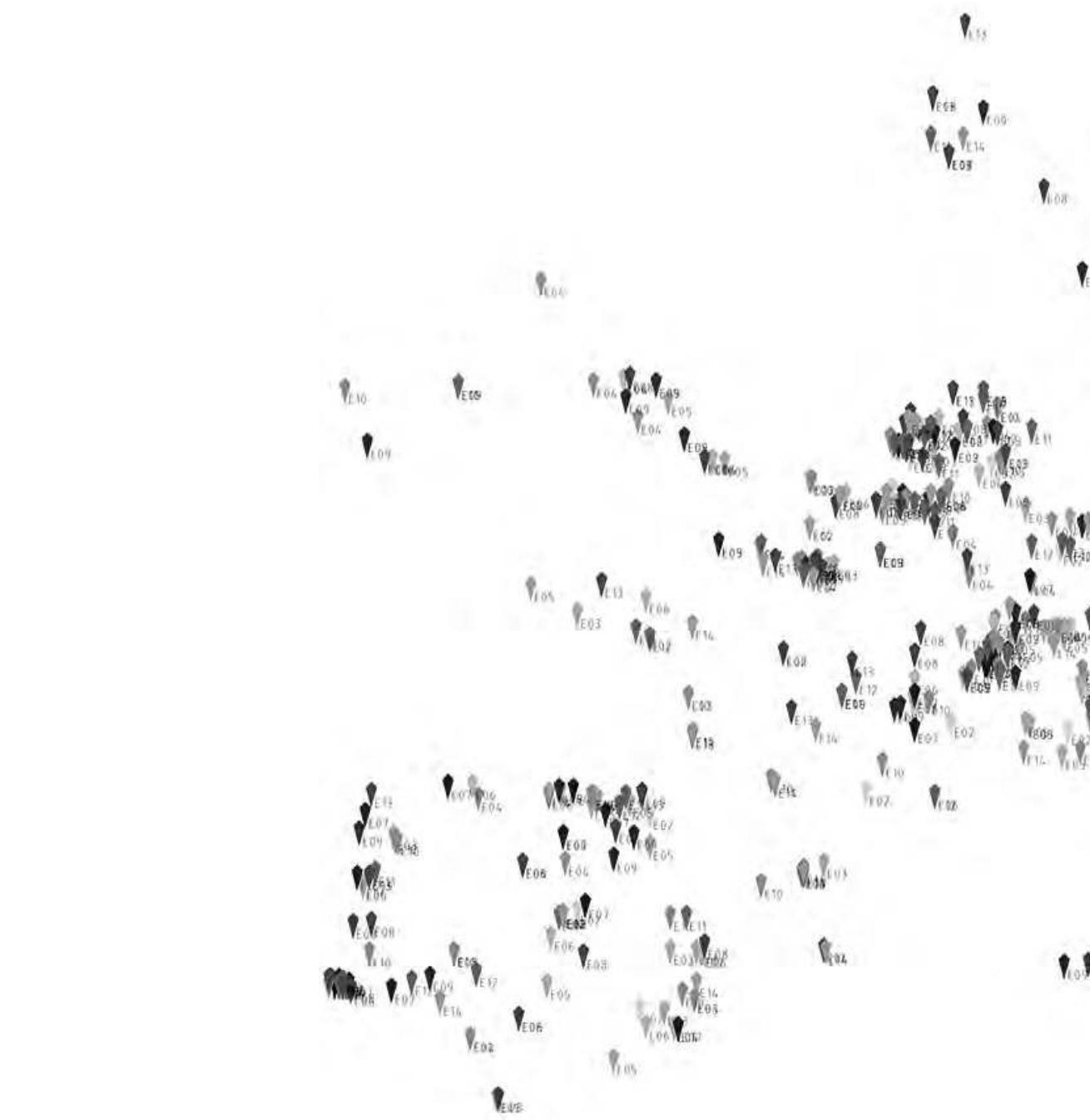

Pso

$\operatorname{lot}_{1}$ 
and economic features of its clients: European cities. At the same time, Europan provides a fertile ground to bounce back from the actual crisis by reflecting through design and formulating possible common futures for a Europe after crisis.

\section{References}

Allemand, S., Ascher, F., Levy, J. (eds) (2004), Le sens du mouvement: modernité et mobilité dans les sociétés urbaines contemporaines, Paris, Belin éditions.

Amphoux, P. (1999), Motricité, mouvance, émotion, in D. Rebois (ed.), Europan 5 Résultats Européens, Paris, Europan Europe editions, pp. 43-52.

Appadurai, A. (2003), Modernity at Large. Cultural Dimensions of Globalization, Minneapolis, University of Minnesota Press.

Appleyard, D. (1982), Livable streets, Berkeley, University of California Press.

Ascher, F., Appel-Muller, M. (eds) (2007), The street belongs to all of us, Paris, éditions Au diable vauvert.

Ascher, F. (1995), Metapolis ou l'avenir des villes, Paris, Éditions Odile Jacob.

Augé, M. (1993), Les non-lieux. Introduction à une anthropologie de la surmodernité, Paris, Éditions du Seuil.

Brickell, K., Datta, A. (eds) (2011), Translocal Geographies: Spaces, Places, Connections, Burlington, Ashgate.

Degros, A. (2014), Networked Territories or a Homage to Structuring Slowness, in D. Rebois (ed.), The Adaptable City 1, Europan 12 Results, Paris, Europan Europe editions, pp. 36-41. Degros, A., Schwab, E. (2019), Relational Rurality: Alternative Mobility as Key to Quality of Life, "Graz Architecture Magazine”, n. 15, pp. 110-119.

Greiner, C., Sakdapolrak, P. (2013), Translocality: Concepts, Applications and Emerging Research Perspectives, "Geography Compass", vol. 7, n. 5, pp. 373-384.

Hamfelt, B. (2004), Architecture and Mobility, in D. Rebois (ed.), Europan 7 European Results Suburban Challenge, Urban Intensity and Housing Diversity, Paris, Europan Europe editions, pp. 15-19.

Kalnis, G. (2016), Collective Intelligence Networks - The Case of Europan Architectural Competition Platform, Doctoral Thesis, Department of Architecture, University of Cyprus.

Lévy, J. (2004), Modèle de mobilité, modèle d'urbanité, in S. Allemand, F. Ascher, J. Levy (eds), Le sens du mouvement: modernité et mobilité dans les sociétés urbaines contemporaines, Paris, Belin éditions, pp. 157-169.

Manzini, E., Staszowski, E. (eds), (2013), Public and Collaborative: Exploring the intersection of design, social innovation and public policy, USA, DESIS Network. 
Provoost, M. (2017), Bottom-Up is Not Enough, in M. Mostafavi (ed.), Ethics of the Urban: The City and the Spaces of the Political, Zurich, Lars Muller, pp. 81-83.

Rebois, D. (ed.) (2007), Generation Europan, Paris, Europan Europe editions.

Rebois, D. (2008), Spaces to share, in D. Rebois (ed.), Europan 9 results, Paris, Europan Europe editions, pp. 10-15.

Rebois, D. (ed.) (2009), What Future for the Europan Competitions? Between Innovation and Negotiation, Paris, Europan Europe editions.

Rebois, D. (2013), Mobility, Rhythms and Urbanity, in S. Stratis (ed.), The UAW Book, About Urban Awareness, Seoul, Damdi editions, pp. 90-94.

Smith, M. P. (2001), Transnational Urbanism. Locating Globalization, Malden (MA), Blackwell.

Smith, M. P. (2011), Translocality: A Critical Reflection, in K. Brickell, A. Datta (eds), Translocal Geographies Spaces, Places, Connections, Farnham, Ashgate, pp. 181-198.

Stratis, S. (2005), Formes de dynamique local/global dans la démarche de projet à l'échelle urbano-architecturale: le contexte Europan, Doctoral Thesis in Urban Studies-Planification-Planning, University of Paris 8 (St Denis), Paris.

Stratis, S. (2006), Urban dynamics of infrastructures, in D. Rebois (ed.), European Urbanity, Europan 8 Results, Paris, Europan Europe editions, pp. 90-93

Stratis, S. (2009), Glocal/Translocal, in D. Rebois (ed.), What Future for the Europan Competitions? Between Innovation and Negotiation, Paris, Europan Europe editions, pp. 28, 29.

Stratis, S. (2016), Negotiate as You Go Along: Infrastructures for Shared Hybrid Territories, in D. Rebois (ed.), Europan 13 Results, Paris, Europan Europe editions.

Stratis, S. (2020), Les défis du projet Europan comme dispositif politique et urbain à l'ère de l'Anthropocène, in "Europan fête ses trente ans” proceedings, Paris, Europan France editions. Vincendon, S. (2019), Europan: The Most Discreet City Planning Competition, (But the Smartest One), Paris, Liberation Daily Press, 9 May.

Vlay, B., Stratis, S. (2010), Making Complicities: Expanding the Project's Territory, in D. Rebois (ed.), Europan 10 Results: Inventing Urbanity, Paris, Europan Europe editions, pp 192-195. Wenderlich, F. (2014), Place, Temporality and Rhythmicity: A New Aesthetic and Methodological Foundation of Urban Design, in M. Carmona (ed.), Exploration in Urban Design: An Urban Design Research Primer, UK, Ashgate, pp. 59-73.

Younes, Ch., Maugard, A. (2019), Villes et architectures en débat - Europan, Paris, Parenthèses editions.

Younes, Ch. (2012), Rhythms and timeframes, (conversation with Stephane Bonzani), in Rebois, D. (ed), Reconnections Europan 11 Results, Paris, Europan Europe editions, pp. 269-274. 